\title{
ANALISIS KAJIAN FAKTOR-FAKTOR YANG DAPAT MEMPENGARUHI KETERLAMBATAN PROYEK JALAN DI JALAN RAYA RANCAEKEK - CILEUNYI NAGREG
}

\author{
Rusito \\ Universitas Sangga Buana YPKP \\ Email: rusito.irep@gmail.com
}

\begin{abstract}
ABSTRAK
Manajemen dalam proyek konstruksi adalah proses bagaimana memanfaatkan sumber daya yang terbatas. Teknik dan alat manajemen adalah sebuah proyek yang dibangun dengan peran penting dalam efektifitas manajemen proyek. Oleh karena itu, manajemen proyek yang baik terletak pada teknik dan alat manajemen yang diperlukan untuk proyek. Keterlambatan dan pembengkakan biaya adalah ukuran ketidaksesuaian waktu dan biaya yang telah diperbaiki. Penelitian ini bertujuan untuk menganalisa faktor penyebab keterlambatan proyek jalan. Penelitian ini menggunakan pendekatan kuantitatif. Pengumpulan data penelitian ini menggunakan kuesioner. Sampel penelitian ini berjumlah 107 kontraktor, konsultan dan pemilik proyek jalan. Analisis data penelitian ini dilakukan analisis faktor. Hasil penelitian ini menunjukkan bahwa faktor utama yang berpengaruh terhadap keterlambatan proyek jalan adalah faktor sumber daya dengan nilai keragaman sebesar $49,18 \%$, selanjutnya faktor biaya dengan nilai keragaman total sebesar 5,32\% dan faktor terakhir yaitu faktor mutu dengan angka keragaman total sebesar $4,43 \%$.
\end{abstract}

Kata Kunci: Keterlambatan, Proyek, Jalan, Sumber Daya Manusia

\section{PENDAHULUAN}

Manajemen dalam proyek konstruksi adalah suatu proses bagaimana memanfaatkan sumber daya yang terbatas (tenaga kerja, uang, peralatan, bahan, dan metode yang digunakan). Teknik dan alat manajemen sebuah proyek konstruksi memegang peranan penting dalam efektifitas manajemen proyek, oleh karena itu, manajemen proyek yang baik terletak pada teknik dan alat manajemen yang digunakan untuk mengelola sebuah proyek. Kesalahan mengelola sumber daya tersebut, akan mengakibatkan proyek tidak efisien dan efektif, seperti terjadinya keterlambatan dan pembengkakan biaya (cost overruns).
Keterlambatan dan pembeng-kakan biaya merupakan dimensi ketidaksesuaian waktu dan biaya yang telah direncanakan. Ketidaksesuaian realisasi dengan ekspektasi pada proyek konstruksi berpotensi menimbulkan kerugian bagi pemilik, kontraktor pelaksana, atau keduanya (Wibowo, 2008). Menurut Praboyo, (1999) keterlambatan adalah sebuah kondisi yang sangat tidak dikehendaki, karena akan sangat merugikan kedua belah pihak dari segi waktu dan biaya. Sedangkan (Santoso, 1999) menyebutkan bahwa pada pelaksanaan proyek konstruksi banyak dijumpai proyek mengalami pembengkakan biaya (cost overruns) maupun keterlambatan waktu. 
Dalam pelaksanaan proyek konstruksi, telah ditentukan dan dibatasi oleh kendalakendala yang sifatnya saling mempengaruhi dan biasa disebut sebagai segitiga project constrain yaitu lingkup pekerjaan (scope), waktu dan biaya. Dimana keseimbangan ketiga constrain tersebut akan menentukan kualitas suatu proyek, perubahan salah satu atau lebih faktor akan mempengaruhi satu faktor lainnya (PMBOK Guide, 2004).

Sebagai salah satu infrasturktur prasarana jalan memegang peranan penting dalam ikut mendorong pertumbuhan perekonomian di suatu wilayah. Tersedianya prasarana jalan yang baik sesuai fungsi dan peranannya akan berdampak pula pada efisiensi bila ditinjau dari segi waktu dan biaya perjalanan.

Dalam rangka membangun prasarana jalan diperlukan penyedia jasa sebagai pelaksana pekerjaan yang akan melaksanakan pembangunan jalan yang dilaksanakan dengan kesepakatan dalam kontrak dimana telah diatur hak dan kewajiban masing-masing pihak. Permasalahan sering timbul pada saat masa pelaksanan kontrak dimana kontrak dibatasi dengan waktu pelaksanaan tertentu, dalam pelaksanaan kontrak sering timbul masalah yang menghambat aktivitas penyelesaian suatu proyek dan masalah lainnya diluar jadual dalam rencana kerja (Nicholas, 1990).
Dalam beberapa kasus dan fenomena dalam pelaksanaan proyek tersebut sering terjadi keterlambatan dalam pelaksanaan pekerjaan sehingga keluar dari kendali jadual waktu yang ditetapkan. Keterlambatan tersebut akan merugikan pihak - pihak terkait baik kontraktor maupun pemilik proyek. Keterlambatan proyek menimbulkan kerugian financial bagi penyedia jasa dikarenakan harus membayar denda keterlambatan sampai maksimum 5 (lima) persen dari nilai kontrak dan dapat mengakibatkan diputuskannya kontrak dan sangsi dimasukkan ke dalam daftar hitam bagi penyedia jasa dimaksud (Perpres No. 54 tahun 2012).

Bagi Pengguna Jasa mengakibatkan terganggunya penyerapan anggaran pembangunan sehingga dapat mengganggu pertumbuhan ekonomi dan tertundanya operasional proyek serta membebani keuangan negara karena harus menganggarkan dana pada tahun anggaran berikutnya bila keterlambatan proyek melampaui akhir bulan Desember tahun anggaran berjalan untuk proyek dengan pelaksanaan tahun tunggal (single years).

Berdasarkan uraian pada latar belakang di atas, maka penulis tertarik untuk melakukan penelitian mengenai "Analisis Kajian Faktor-Faktor yang Dapat Mempengaruhi Keterlambatan Proyek Jalan di Jl. Raya Rancaekek - Cileunyi - 
Nagreg" yang hasilnya akan dituangkan dalam karya tulis ilmiah.

\section{TINJAUAN PUSTAKA}

\section{Penyedia Jasa}

Undang-undang Republik Indonesia No. 2 Tahun 2017 tentang sektor Jasa Konstruksi merupakan kegiatan masyarakat dalam mewujudkan bangunan yang berfungsi sebagai pendukung atau prasarana aktivitas sosial ekonomi kemasyarakatan dan menunjang terwujudnya tujuan pembangunan nasional. Selain pembangunan, Jasa Konstruksi berperan pula untuk mendukung tumbuh dan berkembangnya berbagai industri barang dan jasa yang diperlukan dalam penyelenggaraan Jasa Konstruksi dan secara luas mendukung perekonomian nasional.

Penyelenggaraan Jasa Konstruksi dilaksanakan berlandaskan pada asas kejujuran dan keadilan, manfaat, kesetaraan, keserasian, keseimbangan, profesionalitas, kemandirian, keterbukaan, kemitraan, keamanan dan keselamatan, kebebasan, pembangunan berkelanjutan, serta berwawasan lingkungan.

\section{Proses Manajemen}

Menurut A.D Austen dan R.H Neale (1984), yang dimaksud dengan proses manajamen adalah suatu proses untuk memanfaatkan sumber daya manusia dan sumberdaya lainnya untuk mencapai tujuan tertentu. Manajemen tergantung pada komunikasi yang jelas, dan kemampuan untuk melontorkan pemikiran, gagasan, informasi serta instruksi dengan cepat dan efektif diantara orang-orang yang keterampilan teknis dan minatnya berbeda-beda. Proses manajemen atau sering juga disebut Fungsi Manajemen, dalam satu kesatuan sebagai berikut dibawah ini:

1. Penempatan tujuan (goal setting).

2. Perencanaan (planning).

3. Staffing

4. Directing.

5. Supervising,

6. Pengendalikan (Controlling).

\section{Kegiatan Proyek}

\section{Pengertian Kegiatan Proyek}

Menurut Imam Soeharto (1992), suatu rangkaian kegiatan dapat dibedakan atas dua jenis, yaitu kegiatan rutin dan kegiatan proyek. Kegiatan rutin adalah suatu kegiatan terus menerus yang berulang dan berlangsung lama, sedangkan kegiatan proyek adalah suatu rangkaian kegiatan yang hanya satu kali dilaksanakan dan umumnya berlangsung dalam jangka waktu yang pendek. Oleh karena itu, suatu kegiatan proyek mempunyai awal dan akhir kegiatan yang jelas serta hasil kegiatan yang bersifat unik.

Tahapan Proyek 
Menurut Istiawan Dipohusodo (1996) tahapan konstruksi dibagi menjadi 5 tahap yaitu :

i. Tahap pengembangan konsep, adapun kegiatan yang dilakukan dalan tahap ini adalah melakukan survey pendahuluan dengan investigasi lapangan dimana proyek akan dilaksanakan. Hal ini akan mengungkapkan informasiinformasi yang sangat diperlukan dalam pembuatan konsep proyek. Seperti misalnya informasi mengenai upah tenaga kerja setempat, harga material, perizinan pemerintah setempat, kemampuan penyedia jasa setempat baik kontraktor maupun konsultan, informasi mengenai iklim disekitar lokasi proyek yang digunakan untuk mengantisipasi kendala yang dapat diakibatkan oleh cuaca dan lain sebagainya.

ii. Tahap perencanaan, adapun kegiatan yang dilakukan adalah pengajuan proposal, survey lanjutan, pembuatan desain awal/sketsa rencana (preliminary design) dan perancangan detail (detail design), keempat kegiatan ini tidak dapat dipisahkan satu sama lain karena hasil kegiatan pertama akan berpengaruh pada kegiatan kedua dan selanjutnya.
Tujuan dari tahap ini sebenarnya untuk mendapatkan rencana kerja final yang memuat pengelompokan pekerjaan dan kegiatan secara terperinci.

\section{Keterlambatan Proyek}

\section{Pengertian Keterlambatan}

Pengertian keterlambatan menurut Ervianto (1998) adalah sebagai waktu pelaksanaan yang tidak dimanfaatkan sesuai dengan rencana kegiatan sehingga menyebabkan satu atau beberapa kegiatan mengikuti menjadi tertunda atau tidak diselesaikan tepat sesuai jadwal yang telah direncanakan.

\section{Penyebab Keterlambatan}

Dalam suatu proyek konstruksi banyak yang mungkin terjadi yang dapat mengakibatkan meningkatnya waktu dari suatu kegiatan ataupun mundurnya waktu penyelesaian suatu proyek secara keseluruhan. Beberapa penyebab yang paling sering terjadi antara lain: perubahan kondisi lapangan, perubahan desain atau spesifikasi, perubahan cuaca, ketidak tersedianya tenaga kerja, material, ataupun peralatan. Keterlambatan dalam penyerahan shop drawing / gambar kerja

\section{Tipe Keterlambatan}

a. Excusable delay, yaitu keterlambatan kinerja kontraktor yang terjadi karena faktor yang 
berada diluar kendali kontraktor dan owner. Kontraktor berhak mendapat perpanjangan waktu yang setara dengan keterlambatan tersebut dan tidak berhak atas konpensasinya.

b. Non Excusable delay, yaitu keterlambatan dalam kinerja kontraktor yang terjadi karena kesalahan kontraktor tidak secara tepat melaksanakan kewajiban dalam kontrak. Kontraktor tidak berhak menerima penggantian biaya maupun perpanjangan waktu.

c. Compensable delay, keterlambatan dalam kinerja kontraktor yang terjadi karena kesalahan pihak owner untuk memenuhi dan melaksanakan kewajiban dalam kontrak secara tepat. Dalam hal ini kontraktor berhak atas kompensasi biaya dan perpanjangan waktu.

d. Concurrent delay, yaitu keterlambatan yang terjadi karena dua sebab yang berbeda. Jika excusable delay dan compensable delay terjadi berbarengan dengan non excusable delay maka keterlambatan akan menjadi non excusable delay. Jika compensable delay terjadi berbarengan dengan excusable delay maka keterlambatan akan diberlakukan sebagai excusable delay.

\section{Dampak Keterlambatan}

Menurut Lewis dan Atherley (1996), keterlambatan akan berdampak pada perencanaan semula serta pada masalah keuangan. Keterlambatan dalam suatu proyek konstruksi akan memperpanjang durasi proyek atau meningkatkan biaya maupun kedua-duanya. Adapun dampak keterlambatan pada owner adalah hilangnya potensial income dari fasilitas yang dibangun tidak sesuai waktu yang ditetapkan, sedangkan pada kontraktor adalah hilangnya kesempatan untuk menempatkan sumber dayanya ke proyek lain, meningkatnya biaya tidak langsung (indirect cost) karena bertambahnya pengeluaran untuk gaji karyawan, sewa peralatan serta mengurangi keuntungan.

\section{Mengatasi Keterlambatan}

Menurut Istimawan Dipohusodo (1996), selama proses konstruksi selalu saja muncul gejala kelangkaan periodik atas material-material yang diperlakukan, berupa material dasar atau barang jadi baik yang lokal maupun import. Cara penanganannya sangat bervariasi tergantung pada kondisi proyek, sejak yang ditangani langsung oleh staf khusus dalam organisasi sampai bentuk pembagian porsi tanggung jawab diantara pemberi tugas, kontraktor dan sub- 
kontraktor, sehingga penawaran material suatu proyek dapat datang dari subkontraktor, pemasok atau agen, importir, produsen atau industri yang kesemuanya mengacu pada dokumen perencanaan dan spesifikasi teknis yang telah ditetapkan.

\section{Indikator Keterlambatan}

Menurut Ali, dkk (2012), dampak yang sering terjadi akibat adanya keterlambatan proyek konstruksi, yaitu:

i. Tambahan biaya,

ii. Tambahan waktu penyelesaian proyek,

iii. Keterlambatan pembayaran,

iv. Penjadwalan ulang,

v. Hilangnya produktivitas dan efisiensi tenaga kerja.

\section{METODE PENELITIAN}

\section{Objek Penelitian}

Objek penelitian merupakan sasaran untuk mendapatkan suatu data. Sesuai dengan pengertian objek penelitian yang dikemukakan oleh Sugiyono (2010:13), objek penelitian adalah sasaran ilmiah untuk mendapatkan data dengan tujuan dan kegunaan tertentu tentang sesuatu hal objektif, valid, dan reliable tentang sesuatu hal (variabel tertentu). Objek dalam penelitian ini adalah faktor-faktor yang mempengaruhi keterlambatan proyek jalan di Jl. Raya Rancaekek - Cileunyi - Nagreg.
Sedangkan penelitian ini dilakukan di Jl. Raya Rancaekek - Cileunyi - Nagreg pada proyek jalan yang telah dibangun dari tahun 2017 sampai dengan tahun 2018.

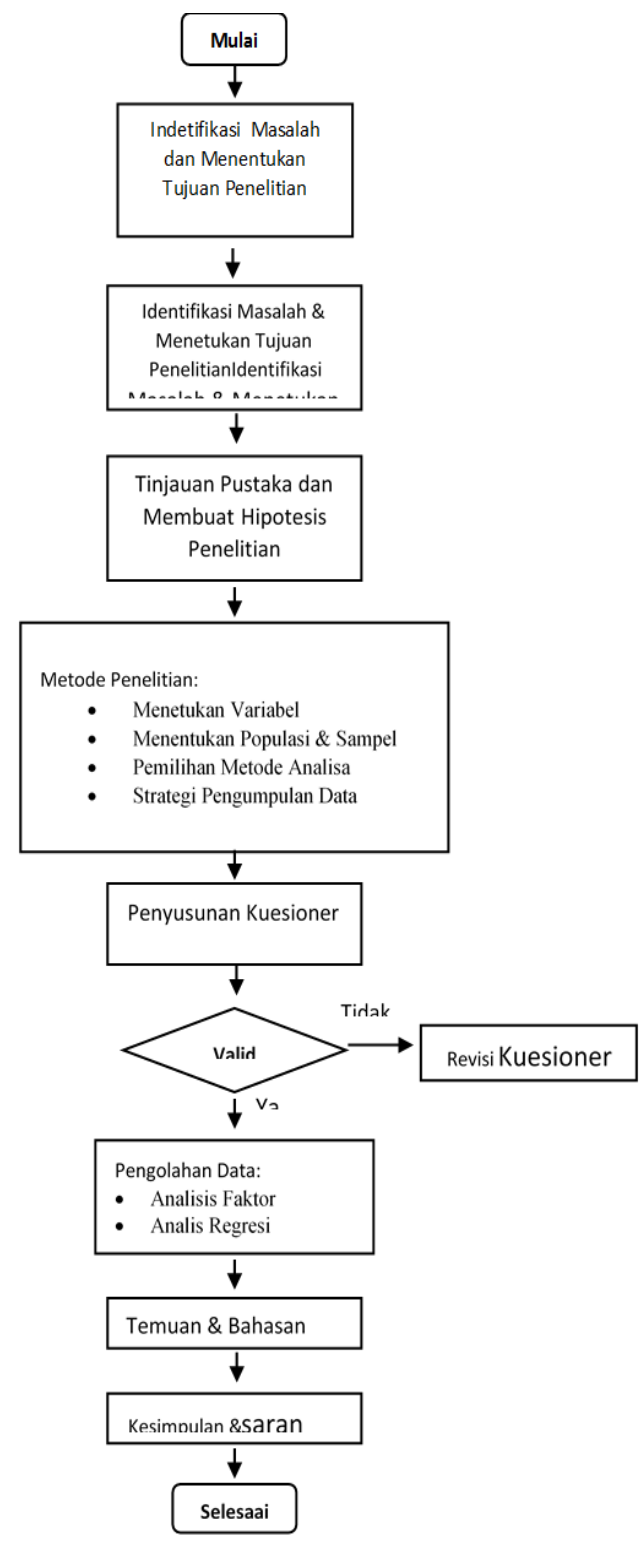

Gambar 3.1 Flowchart Penelitian

\section{Metodologi Penelitian}

Dalam penelitian ini, penulis akan melakukan langkah-langkah penelitian sebagai berikut: 


\section{Metode yang Digunakan}

Metode penelitian yang digunakan adalah metode survey. Menurut Sugiyono (2009:13) "Bahwa metode survey digunakan untuk mendapatkan data dari tempat tertentu yang alamiah (bukan buatan), tetapi peneliti melakukan perlakuan dalam pengumpulan data, misalnya dengan mengedarkan kuesioner, test, wawancara terstruktur dan sebagainya (perlakuan tidak seperti dalam eksperimen)". Penggunaan metode survey akan memudahkan peneliti untuk memperoleh data untuk diolah dengan tujuan memecahkan masalah yang menjadi tujuan akhir suatu penelitian. Adapun langkah-langkah yang bisa dilakukan dalam pelaksanaan survey menurut Singaribun (2011:12-13) adalah :

1) Merumuskan masalah penelitian dan menentukan tujuan survei
2) Menentukan konsep dan hipotesa serta menggali kepustakaan

3) Pengambilan sampel

4) Pembuatan kuesioner

5) Pekerjaan lapangan

6) Pengolahan data

7) Analisa dan pelaporan

Pengguna metode survey untuk mempermudah peneliti melaksanakan penelitian, pada metode penelitian menjelaskan mengenai prosedur penelitian yang akan dilaksanakan sebagai cara ilmiah untuk mendapatkan data dengan tujuan dan kegunaan tertentu. Tujuan metode penelitian untuk mencari informasi data penelitian dari pertanyaan dapat terungkap secara faktua dan terperinci yang menggambarkan fenomena yang ada.

\section{Operasionalisasi Variabel}

Operasionalisasi variabel dalam penelitian ini diturunkan ke dalam dimensi dan indikator seperti Tabel 3.1 sebagai berikut:

Tabel 3.1 Operasionalisasi Variabel

\begin{tabular}{|c|c|}
\hline & Indikator \\
\hline \multirow[t]{5}{*}{$\begin{array}{l}\text { Faktor-faktor } \\
\text { Manajemen Proyek } \\
\text { (X) }\end{array}$} & $\begin{array}{l}\text { Bahan dasar dan materil yang dipakai untuk bangunan telah } \\
\text { bersesuaian dengan standar yang telah ditetapkan dan disepakati } \\
\text { bersama }\end{array}$ \\
\hline & $\begin{array}{l}\text { Teknik mencampur bahan materil dilapangan telah menggunakan } \\
\text { perbandingan, pemakaian yang sesuai dengan ketentuan yang } \\
\text { semestinya. }\end{array}$ \\
\hline & $\begin{array}{l}\text { Dalam pelaksanaan proyek di lapangan mutu sebuah pekerjaan } \\
\text { dalam proses pembangunan jalan sangat diperhatikan dengan baik }\end{array}$ \\
\hline & $\begin{array}{l}\text { Target penyelesaian pekerjaan di lapangan selalu diupayakan sesuai } \\
\text { dengan waktu yang telah direncanakan. }\end{array}$ \\
\hline & $\begin{array}{l}\text { Dalam proses penyelesaian proyek pembangunan waktu pelaksanaan } \\
\text { sangat memperhatikan aktualisasi Kurva 's' secara baik. }\end{array}$ \\
\hline
\end{tabular}




\begin{tabular}{|c|c|}
\hline & $\begin{array}{l}\text { Cara pelaksanaan pekerjaan dilapangan diupayakan seifisien dan } \\
\text { seefektif mungkin guna mengejar waktu yang direncanakanan }\end{array}$ \\
\hline & $\begin{array}{l}\text { Pelaksanaan proyek dilapangan sangat memperhatikan efesiensi } \\
\text { biaya yang dikeluarkan }\end{array}$ \\
\hline & $\begin{array}{l}\text { Proses negosiasi resource sangat diutamakan guna menghasilkan } \\
\text { penghematan biaya sebaik-baiknya }\end{array}$ \\
\hline & $\begin{array}{l}\text { Inovasi dalam hal proses pembangunan perlu dilakukan guna } \\
\text { menghasilkan efesiensi biaya }\end{array}$ \\
\hline & $\begin{array}{l}\text { Pengelolaan sumber daya manusia di lapangan ketika proses } \\
\text { pembangunan harus dilakukan seprofesional mungkin }\end{array}$ \\
\hline & $\begin{array}{l}\text { Pembentukan organisasi kerja dilapangan mutlak dilakukan guna } \\
\text { menghasilkan proyek kerja yang baik }\end{array}$ \\
\hline & $\begin{array}{l}\text { Staf yang bertanggung jawab dalam pelaksanaan proyek dilapangan } \\
\text { sangat diperlukan guna menghasilkan kinerja proyek yang baik }\end{array}$ \\
\hline & $\begin{array}{l}\text { Pembentukan tim harus dilakukan sejak awal untuk mengkordinasi } \\
\text { antar bagian }\end{array}$ \\
\hline & $\begin{array}{l}\text { Pegawai harus dimotivasi dengan sebaik-baiknya supaya dapat } \\
\text { menghasilkan kinerja yang terbaik }\end{array}$ \\
\hline & $\begin{array}{l}\text { Hierarki kekuasaan dalam proyek harus dibuat sesuai dengan } \\
\text { kapasitas masing-masing pekerja. }\end{array}$ \\
\hline & $\begin{array}{lllll}\text { Efektifitas dalam pengerjaan proyek merupakan hal yang } \\
\text { diutamakan dalam diri setiap pekerja. }\end{array}$ \\
\hline & Terdapat kejelasan otoritas kerja di lapangan untuk setiap bagian \\
\hline & $\begin{array}{l}\text { Pekerja akan diberikan penugasan kerja sesuai dengan keahlian di } \\
\text { bidang masing-masing }\end{array}$ \\
\hline & $\begin{array}{l}\text { Biaya utnuk mengoptimalkan kemampuan pekerja di dalam bekerja } \\
\text { senantiasa teralokasi secara rutin }\end{array}$ \\
\hline & $\begin{array}{l}\text { Perusahaan akan memberikan sanksi yang tegas bagi pekerja yang } \\
\text { melanggar peraturan yang berlaku }\end{array}$ \\
\hline & $\begin{array}{l}\text { Tantangan pekerjaan akan diberikan kepada setiap individu yang } \\
\text { bekerja diperusahaan }\end{array}$ \\
\hline & $\begin{array}{l}\text { Setiap pekerja akan memperoleh pelatihan guna meningkatkan } \\
\text { keahlian teknis dilapangan }\end{array}$ \\
\hline & $\begin{array}{l}\text { Rasa kebersamaan dan team work perlu dibina dikalangan pekerja } \\
\text { proyek. }\end{array}$ \\
\hline Keterlambatan & Tambahan biaya \\
\hline Proyek (Y) & Tambahan waktu penyelesaian proyek \\
\hline & Keterlambatan pembayaran \\
\hline & Penjadualan ulang \\
\hline & Hilangnya produktivitas dan efisiensi tenaga kerja \\
\hline
\end{tabular}

\section{Populasi dan Sampel Penelitian}

Definisi populasi menurut Sugiyono (2010:115) adalah wilayah generalisasi yang terdiri atas objek/subjek yang mempunyai kualitas dan karakteristik tertentu yang ditetapkan oleh peneliti untuk mempelajari kemudian ditarik kesimpulan. Berdasarkan pengertian di atas, populasi bukan sekedar jumlah yang ada pada objek atau subjek yang dipelajari, 
tetapi meliputi seluruh karakteristik atau sifat yang dimiliki oleh objek atau subjek tersebut. Populasi sasaran merupakan populasi yang digunakan untuk menjadi sasaran dalam penelitian. Populasi yang digunakan dalam penelitian ini adalah seluruh kontraktor, konsultan dan pemilik yang terlibat dalam pembangunan proyek jalan di Jl. Raya Rancaekek - Cileunyi Nagreg.

Pengertian sampel menurut Sugiyono (2011: 298-299), Sampel adalah sebagian dari populasi. Penelitian berangkat dari populasi tertentu, tetapi karena keterbatasan tenaga, dana, waktu dan pikiran, maka peneliti menggunakan sampel sebagai obyek yang dipelajari atau sebagai sumber data. Teknik pengambilan sampel yang digunakan pada penelitian ini adalah Purposive sampling. Purposive Sampling adalah teknik penentuan sampel berdasarkan pertimbangan kriteria dan ketentuan tertentu (Sugiyono, 2010:70). Kriteria yang ditentukan peneliti adalah bahwa responden adalah kontraktor, konsultan dan pemilik yang memiliki tingkat pemahaman terhadap variabel yang ditanyakan. Berdasarkan kriteria pengambilan sampel tersebut maka jumlah sampel yang digunakan dalam penelitian ini ada sebanyak 107 responden.

\section{Teknik Pengumpulan Data}

Teknik pengumpulan data, menjelaskan bagaimana sumber diperoleh dan darimana sumber diperoleh. Dalam penelitian ini penyusun menggunakan beberapa teknik pengumpulan data, diantaranya :

1. Studi kepustakaan, yaitu pengambilan data dengan cara mempelajari buku-buku dan dokumen yang berhubungan dengan pokok-pokok penelitian. Studi kepustakaan ini bertujuan untuk menjaring data sekunder sebagai bahan referensi dalam membantu melakukan analisis terhadap permasalahan yang ada dilapangan.

2. Studi Lapangan, yaitu teknik pengambilan data dengan melakukan pengamatan langsung pada objek penelitian. Studi lapangan ini menggunakan tiga bentuk kegiatan yaitu:

\section{Rancangan Analisis dan Uji Hipotesis}

\section{Uji Validitas}

Uji validitas digunakan untuk mengukur sah atau valid tidaknya suatu kuisioner. Suatu kuisioner sebagai instrument penelitian dinyatakan valid jika pertanyaan pada kuisioner tersebut, Ghozali (2011). Suatu tes dikatakan memiliki validitas tinggi apabila tes tersebut menjalankan 
fungsi ukurnya atau memberikan hasil dengan maksud digunakannya tes tersebut. Dalam uji validitas ini digunakan teknik korelasi Product Moment denganrumus:

$r=\frac{N\left(\sum X Y\right)-\left(\sum X \sum Y\right)}{\sqrt{\left\{N \sum X^{2}-\left(\sum X\right)^{2}\right\}}\left\{N \sum Y^{2}-\left(\sum Y\right)^{2}\right\}}$

Dimana :

$\begin{array}{ll}\text { rhitung } & =\text { koefisien korelasi } \\ \sum \mathbf{X i} & =\text { jumlah skor item } \\ \sum \mathbf{Y i} & =\text { jumlah skor total } \\ \mathrm{n} & =\text { jumlah responden }\end{array}$

(Suharsimi Arikunto, 2006:170)

Dengan menggunakan taraf signifikan $\alpha=$ 0,05 koefisien korelasi yang diperoleh dari hasil perhitungan dibandingkan dengan nilai dari tabel korelasi nilai $r$ dengan derajat kebebasan (n-2), dimana menyatakan jumlah banyaknya responden. Jika $r_{\text {hitung }}>r_{0,05}$ dikatakan valid, sebaliknya jika $\mathrm{r}_{\text {hitung }} \leq \mathrm{r}_{0,05}$ tidak valid.

\section{Uji Reliabilitas}

Tes reliabilitas adalah tes yang digunakan dalam penelitian untuk mengetahui apakah alat pengumpul data yang digunakan menunjukan tingkat ketepatan, tingkat keakuratan, kestabilan, dan konsistensi dalam mengungkapkan gejala dari sekelompok individu walaupun dilaksanakan pada waktu yang berbeda. Untuk menghitung uji reliabilitas, penelitian ini menggunakan rumus alpha dari Cronbach sebagaimana berikut:

$$
r_{11}=\left[\frac{k}{k-1}\right]\left[1-\frac{\sum \sigma_{n}{ }^{2}}{\sigma_{t}^{2}}\right]
$$

(Suharsimi Arikunto, 2002:171)

Dimana :

$\mathrm{r}_{11} \quad=$ reliabilitas instrumen

$\mathrm{k}=$ banyak butir pernyataan atau banyaknya soal

$\sum \sigma_{\mathrm{n}}^{2}=$ Jumlah varians butir

$\sigma_{\mathrm{t}}{ }^{2} \quad=$ varians total

Pengukuran reliabilitas dilakukan dengan cara one shot atau pengukuran sekali saja dengan alat bantu SPSS uji statistik Cronbach Alpha $(\alpha)$. Suatu konstruk atau variabel dikatakan reliable jika memberikan nilai Cronbach Alpha $>0,70$ (Nunnally dalam Ghozali, 2011:25).

\section{Metoda Analisis Data}

Tujuan analisis adalah menyederhanakan data ke dalam bentuk yang lebih mudah dibaca dan diinterprestasi. Dalam proses ini sering kali digunakan statistik karena memang salah satu fungsi statistik adalah menyederhanakan data. Adapun metode analisis yang akan digunakan antara lain:

\section{Menentukan Skor Terhadap Pernyataan Kuesioner}

Setelah pernyataan-pernyataan ditentukan, maka langkah selanjutnya adalah menentukan skor untuk pernyataanpernyataan tersebut. Dalam penelitian ini skala pengukuran data memiliki skala 
ordinal yang menunjukkan perbedaan tingkatan subyek secara kuantitatif, seperti data yang dinyatakan dalam bentuk peringkat atau ranking. Persepsi responden dapat diurut menjadi : Tidak berpengaruh; agak berpengaruh; berpengaruh dan sangat berpengaruh. Kemudian data kuantitatif tersebut dirubah menjadi data kuantitatif sebagai berikut : Sangat tidak setuju diberi nilai 1; Tidak setuju diberi nilai 2; Cukup setuju diberi nilai 3; Setuju diberi nilai 4 dan Sangat setuju diberi nilai 5.

\section{Menentukan Ranking Pada Jawaban}

\section{Responden}

Untuk menentukan ranking atau peringkat dari faktor penyebab keterlambatan pada Proyek Jalan di Jl. Raya Rancaekek Cileunyi - Nagreg secara umum pada jawaban responden dianalisis dengan indeks kepentingan berdasarkan nilai ratarata persepsi responden dengan menggunakan rumus pada persamaan berikut ini :

Mean $=I=\sum \frac{a_{i} X_{i}}{N}$

\section{Dengan :}

$\mathrm{I}=$ Indeks Kepentingan

$\mathrm{Xi}=$ frekuensi respon dari setiap persepsi ai $=$ nilai atas persepsi yang diberikan $(1,2,3,4,5)$

$\mathrm{N}=$ jumlah data

Dari hasil indeks kepentingan ini akan dihasilkan peringkat dari masing- masing faktor penyebab keterlambatan proyek Jalan di Jl. Raya Rancaekek - Cileunyi Nagreg tersebut sehingga dapat diketahui faktor utamanya. Selanjutnya setelah diketahui faktor utama dari penyebab keterlambatan tersebut, maka dijabarkan lagi kedalam sub-faktor dan kemudian ditentukan peringkat atau ranking dengan menggunakan rumus yang sama yaitu persamaan diatas terhadap item-item sub faktor tersebut.

Furqon (1997) faktor penilaian pada harga rata-rata dibuat batasan sebagai berikut : harga rata-rata kurang dari 0,5 dianggap tidak berpengaruh, 0,5 s/d 1,5 dianggap agak berpengaruh, lebih besar 1,5 s/d 2,5 dianggap berpengaruh lebih besar $2,5 \mathrm{~s} / \mathrm{d}$ 3,0 dianggap sangat berpengaruh.

\section{Analisis Faktor}

Untuk mengetahui faktor yang paling berpengaruh maka akan dilakukan analisis faktor. Analisis faktor dilakukan untuk penyederhanaan jumlah variabel yang cukup besar menjadi beberapa kelompok yang lebih kecil. Analisis dilakukan berdasarkan faktor yang sama akan tetapi tetap mempertahankan sebanyak mungkin informasi aslinya. Sedangkan untuk mereduksi sejumlah variabel test menjadi variabel yang lebih kecil dilakukan analisis komponen dan faktor yakni berhubungan dengan korelasi antar komponen.

Analisis Regresi Linear 
Analisis regresi linear digunakan untuk mengukur pengaruh antara variabel $\mathrm{X}$ dengan variabel $\mathrm{Y}$ dalam penelitian ini diolah melalui program IBM SPSS 23. Analisis ini digunakan untuk mengetahui seberapa besar pengaruh variabel bebas terhadap variabel terikatnya dengan model persamaan sebagai berikut:

$\mathrm{Y}=\mathrm{a}+\beta_{1} \mathrm{X}_{1}+\beta_{2} \mathrm{X}_{2}+\ldots+\beta_{\mathrm{k}} \mathrm{X}_{\mathrm{k}}++\mathrm{e}$

Koefisien $\beta$ bernilai positif $(+)$ berarti hubungan yang searah antara variabel bebas dengan variabel terikat. Dengan kata lain, peningkatan (penurunan) besarnya variabel bebas akan diikuti oleh besarnya peningkatan (penurunan) besarnya variabel terikat. Sedangkan jika koefisiensi $\beta$ bernilai negatif (-) berarti hubungan yang berlawanan arah antara variabel bebas dengan variabel terikat. Dengan kata lain, setiap peningkatan (penurunan) besarnya nilai variabel bebas akan diikuti oleh penurunan (peningkatan) besarnya nilai variabel terikat

\section{HASIL DAN PEMBAHASAN}

Pada bab ini, penulis akan memaparkan dan menganalisis data yang terkumpul dari hasil observasi di lapangan mengenai kajian faktor-faktor yang dapat menyebabkan keterlambatan proyek Jalan

Tabel 4.1 Hasil Uji Validitas Variabel di Jl. Raya Rancaekek - Cileunyi - Nagreg. Dalam penelitian ini sampel yang digunakan adalah kontraktor, konsultan dan pemilik yang memiliki tingkat pemahaman terhadap variabel yang ditanyakan dalam hal ini terdiri dari 107 responden. Data yang digunakan berupa data primer melalui penyebaran kuesioner yang dibagikan kepada responden tersebut kemudian diolah dengan menggunakan analisis faktor dan analisis regresi.

\section{Pengujian Instrument Penelitian}

Sebelum hasil tanggapan responden berdasarkan kuesioner dianalisis lebih lanjut, perlu dilakukan pengujian terhadap instrument data yang digunakan dengan menggunakan uji validitas dan reliabilitas sebagai berikut:

\section{Uji Validitas}

Teknik korelasi yang digunakan adalah Pearson Correlation Product Moment. Kriteria validitas tiap itemnya atau butir pertanyaan adalah jika $r_{\text {hitung }}>r_{\text {tabel, }}$ dimana nilai $\mathrm{r}_{\text {tabel }}(0.05 ; \mathrm{dk}=107-2)$ sebesar 0.19 , maka item atau butir tersebut dinyatakan valid. Adapun hasil uji validitas kuesioner kedua puluh tiga variabel yang diteliti disajikan pada tabel berikut:

\begin{tabular}{|l|l|l|l|}
\hline Pernyataan & $\mathbf{r}_{\text {hitung }}$ & $\mathbf{r}_{(\mathbf{0}, \mathbf{0 5} ; \mathbf{1 0 5})}$ & Ket. \\
\hline $\mathrm{X} 1$ & 0.680 & 0.19 & Valid \\
\hline $\mathrm{X} 2$ & 0.655 & 0.19 & Valid \\
\hline
\end{tabular}




\begin{tabular}{|l|l|l|l|}
\hline Pernyataan & $\mathbf{r}_{\text {hitung }}$ & $\mathbf{r}_{(\mathbf{0} \mathbf{0 5} ; \mathbf{1 0 5})}$ & Ket. \\
\hline X3 & 0.668 & 0.19 & Valid \\
\hline X4 & 0.689 & 0.19 & Valid \\
\hline X5 & 0.776 & 0.19 & Valid \\
\hline X6 & 0.701 & 0.19 & Valid \\
\hline X7 & 0.682 & 0.19 & Valid \\
\hline X8 & 0.670 & 0.19 & Valid \\
\hline X9 & 0.690 & 0.19 & Valid \\
\hline X10 & 0.696 & 0.19 & Valid \\
\hline X11 & 0.631 & 0.19 & Valid \\
\hline X12 & 0.714 & 0.19 & Valid \\
\hline X13 & 0.735 & 0.19 & Valid \\
\hline X14 & 0.704 & 0.19 & Valid \\
\hline
\end{tabular}

\begin{tabular}{|l|l|l|l|}
\hline Pernyataan & $\mathbf{r}_{\text {hitung }}$ & $\mathbf{r}_{(\mathbf{0}, \mathbf{0 5} ; \mathbf{1 0 5})}$ & Ket. \\
\hline X15 & 0.710 & 0.19 & Valid \\
\hline X16 & 0.669 & 0.19 & Valid \\
\hline X17 & 0.682 & 0.19 & Valid \\
\hline X18 & 0.725 & 0.19 & Valid \\
\hline X19 & 0.698 & 0.19 & Valid \\
\hline X20 & 0.743 & 0.19 & Valid \\
\hline X21 & 0.736 & 0.19 & Valid \\
\hline X22 & 0.737 & 0.19 & Valid \\
\hline X23 & 0.721 & 0.19 & Valid \\
\hline
\end{tabular}

Sumber: Hasil Pengolahan Peneliti dengan IBM SPSS 23, 2018

Pada tabel 4.1 terlihat bahwa nilai indeks validitas pada masing-masing item pertanyaan yang diukur melalui nilai korelasi product moment yang memiliki

Tabel 4.3 Tanggapan Responden Terhadap Faktor Penyebab Keterlambatan Proyek

\begin{tabular}{|l|l|l|l|l|l|l|l|}
\hline No & \multicolumn{3}{|c|}{ Pernyataan } & \multicolumn{5}{|c|}{ Jumlah } \\
\cline { 2 - 8 } 1 & 5 & 4 & 3 & 2 & 1 & \\
\hline & $\begin{array}{l}\text { Bahan dasar dan materil yang dipakai } \\
\text { untuk bangunan telah bersesuaian dengan } \\
\text { standar yang telah ditetapkan dan } \\
\text { disepakati bersama }\end{array}$ & 14 & 30 & 39 & 19 & 5 & 107 \\
\hline 2 & $\begin{array}{l}\text { Teknik mencampur bahan materil } \\
\text { dilapangan telah menggunakan } \\
\text { perbandingan, pemakaian yang sesuai } \\
\text { dengan ketentuan yang semestinya. }\end{array}$ & 19 & 33 & 30 & 19 & 6 & 107 \\
\hline 3 & $\begin{array}{l}\text { Dalam pelaksanaan proyek dilapangan } \\
\text { mutu sebuah pekerjaan dalam proses } \\
\text { pembangunan bangunan sangat } \\
\text { diperhatikan dengan baik }\end{array}$ & 13 & 30 & 34 & 26 & 4 & 107 \\
\hline 4 & $\begin{array}{l}\text { Target penyelesaian pekerjaan dilapangan } \\
\text { selalu diupayakan sesuai dengan waktu } \\
\text { yang telah direncanakan. }\end{array}$ & 22 & 30 & 38 & 13 & 4 & 107 \\
\hline 5 & $\begin{array}{l}\text { Dalam proses penyelesaian proyek } \\
\text { pembangunan waktu pelaksanaan sangat } \\
\text { memperhatikan aktualisasi Kurva s's } \\
\text { secara baik. }\end{array}$ & 40 & 31 & 15 & 3 & 107 \\
\hline 6 & $\begin{array}{l}\text { Cara pelaksanaan pekerjaan dilapangan } \\
\text { diupayakan seifisien dan seefektif } \\
\text { mungkin guna mengejar waktu yang } \\
\text { direncanakanan }\end{array}$ & 42 & 26 & 13 & 7 & 107 \\
\hline
\end{tabular}


ISSN 1979-4835

\begin{tabular}{|c|c|c|c|c|c|c|c|}
\hline 7 & $\begin{array}{l}\text { Pelaksanaan proyek dilapangan sangat } \\
\text { memperhatikan efesiensi biaya yang } \\
\text { dikeluarkan }\end{array}$ & 16 & 30 & 33 & 23 & 5 & 107 \\
\hline 8 & $\begin{array}{l}\text { Proses negosiasi resource sangat } \\
\text { diutamakan guna } \text { menghasilkan } \\
\text { penghematan biaya sebaik-baiknya }\end{array}$ & 17 & 34 & 32 & 18 & 6 & 107 \\
\hline 9 & $\begin{array}{l}\text { Inovasi dalam hal proses pembangunan } \\
\text { perlu dilakukan guna menghasilkan } \\
\text { efesiensi biaya }\end{array}$ & 18 & 33 & 28 & 22 & 6 & 107 \\
\hline 10 & $\begin{array}{l}\text { Pengelolaan sumber daya manusia di } \\
\text { lapangan ketika proses pembangunan } \\
\text { harus dilakukan seprofesional mungkin }\end{array}$ & 15 & 28 & 43 & 15 & 6 & 107 \\
\hline 11 & $\begin{array}{l}\text { Pembentukan organisasi kerja dilapangan } \\
\text { mutlak dilakukan guna menghasilkan } \\
\text { proyek kerja yang baik }\end{array}$ & 19 & 30 & 42 & 13 & 3 & 107 \\
\hline 12 & $\begin{array}{l}\text { Staf yang bertanggung jawab dalam } \\
\text { pelaksanaan proyek dilapangan } \\
\text { diperlukan guna menghasilkan kinerja } \\
\text { proyek yang baik }\end{array}$ & 18 & 38 & 32 & 14 & 5 & 107 \\
\hline 13 & $\begin{array}{l}\text { Pembentukan tim harus dilakukan sejak } \\
\text { awal untuk mengkordinasi antar bagian }\end{array}$ & 20 & 32 & 30 & 18 & 7 & 107 \\
\hline 14 & $\begin{array}{l}\text { Pegawai harus dimotivasi dengan sebaik- } \\
\text { baiknya supaya dapat menghasilkan } \\
\text { kienerja yang terbaik }\end{array}$ & 17 & 32 & 33 & 22 & 3 & 107 \\
\hline 15 & $\begin{array}{l}\text { Hierarki kekuasaan dalam proyek harus } \\
\text { dibuat sesuai dengan kapasitas masing- } \\
\text { masing pekerja. }\end{array}$ & 22 & 24 & 35 & 21 & 5 & 107 \\
\hline 16 & $\begin{array}{l}\text { Efektifitas dalam pengerjaan proyek } \\
\text { merupakan hal yang diutamakan dalam diri } \\
\text { setiap pekerja. }\end{array}$ & 19 & 35 & 28 & 19 & 6 & 107 \\
\hline 17 & $\begin{array}{l}\text { Terdapat kejelasan otoritas } \\
\text { dilapangan untuk setiap bagian }\end{array}$ & 17 & 39 & 29 & 18 & 4 & 107 \\
\hline 18 & $\begin{array}{l}\text { Pekerja akan diberikan penugasan kerja } \\
\text { sesuai dengan keahlian di bidang masing- } \\
\text { masing }\end{array}$ & 17 & 31 & 34 & 22 & 3 & 107 \\
\hline 19 & $\begin{array}{l}\text { Biaya utnuk mengoptimalkan kemampuan } \\
\text { pekerja di dalam bekerja senantiasa } \\
\text { teralokasi secara rutin }\end{array}$ & 15 & 32 & 37 & 18 & 5 & 107 \\
\hline 20 & $\begin{array}{l}\text { Perusahaan akan memberikan sanksi yang } \\
\text { tegas bagi pekerja yang melanggar } \\
\text { peraturan yang berlaku }\end{array}$ & 20 & 30 & 33 & 17 & 7 & 107 \\
\hline 21 & $\begin{array}{l}\text { Tantangan pekerjaan akan diberikan } \\
\text { kepada setiap individu yang bekerja } \\
\text { diperusahaan }\end{array}$ & 17 & 32 & 37 & 17 & 4 & 107 \\
\hline 22 & $\begin{array}{l}\text { Setiap pekerja akan memperoleh pelatihan } \\
\text { guna meningkatkan keahlian teknis } \\
\text { dilapangan }\end{array}$ & 24 & 26 & 28 & 26 & 3 & 107 \\
\hline 23 & $\begin{array}{l}\text { Rasa kebersamaan dan team work perlu } \\
\text { dibina dikalangan pekerja proyek. }\end{array}$ & 27 & 27 & 33 & 19 & 1 & 107 \\
\hline
\end{tabular}


Uji Reliabilitas

Pengukuran reliabilitas dengan uji statistic

Cronbach Alpha ( $\alpha$ ). Suatu konstruk atau

Tabel 4.2 Hasil Uji Reliabilitas Kuesioner

\begin{tabular}{|l|l|l|l|}
\hline Variabel & $\begin{array}{l}\text { Cronbach's } \\
\text { Alpha }\end{array}$ & $\begin{array}{l}\text { Nilai } \\
\text { Kritis }\end{array}$ & Ket. \\
\hline $\begin{array}{l}\text { Faktor-faktor } \\
\text { Penyebab } \\
\text { Keterlambatan }\end{array}$ & 0.953 & 0.6 & Reliabel \\
\hline
\end{tabular}

Sumber: Hasil Pengolahan Peneliti dengan IBM SPSS 23, 2018

Berdasarkan tabel 4.2 nilai reliabilitas butir pernyataan pada kuesioner keenam variabel yang sedang diteliti lebih besar dari 0.60 hasil ini menunjukkan bahwa butir kuesioner pada faktor-faktor penyebab keterlambatan proyek handal untuk mengukur variabelnya masingmasing serta dapat dikatakan memiliki ketepatan yang tinggi untuk dijadikan variabel pada suatu penelitian.

\section{Tanggapan Responden Terhadap}

\section{Faktor Penyebab Keterlambatan}

\section{Proyek Jalan}

Berdasarkan hasil pengumpulan data melalui penyebaran kuesioner yang dibagikan kepada 107 responden diperoleh hasil penelitian berkaitan dengan tanggapan responden terhadap faktor penyebab keterlambatan penyelesaian proyek yang disajikan dalam tabel 4.3. variabel dikatakan reliabel jika memberikan nilai Cronbach Alpha $>0.60$. Hasil pengujian reliabilitas adalah sebagai berikut:

\section{Hasil Pencapaian Pada Faktor- Faktor Penyebab Keterlambatan Penyelesaian Proyek}

Setelah diketahui distribusi frekuensi yang disajikan dalam tabel 4.3 di atas maka langkah selanjutnya adalah melakukan analisis data dan pembahasan mengenai tingkat pencapaian dari faktor-faktor penyebab keterlambatan dalam penyelesaian proyek. Untuk mengetahui item penyataan mana saja yang memberikan pencapaian tertinggi dan pencapaian terendah pada faktor-faktor penyebab keterlambatan penyelesaian proyek, maka akan dilakukan perhitungan dengan menggunakan indeks kepentingan sehingga diketahui peringkat atau rangking item-item dari jawaban responden dengan persamaan sebagai berikut:

$$
\text { Mean }=I=\sum_{i=1}^{5} \frac{a_{i} x_{i}}{N}
$$

Keterangan:

$a_{i}=$ Frekuensi data

$\mathrm{xi}=$ nilai data

$\mathrm{N}=$ jumlah data

Berdasarkan perhitungan dengan menggunakan persamaan di atas maka 
diperoleh rangking dari pencapaian pada setiap faktor dan rangking dari aktor yang menyebabkan keterlambatab dari setiap item dari data yang secara lengkap disajikan sebagai berikut

Berdasarkan faktor-faktor yang menyebabkan keterlambatan proyek Jalan dari yang paling berpengaruh sampai dengan yang tidak terlalu berpengaruh. Diperoleh bahwa variabel perlu adanya kebersamaan dan team work dalam sebuah proyek, hal ini dapat dilihat berdasarkan rata-rata skor yang diperoleh sebesar 3.56, selanjutnya adalah berkaitan dengan proses penyelesaian proyek memperhatikan aktualisasi Kurva ' $\mathrm{s}$ ' memiliki rata-rata skor sebesar 3.51, serta kesesuaian penyelesaian pekerjaan dengan target dilapangan dan pelaksanaan pekerjaan dilapangan diupayakan seifisien dan seefektif mungkin dengan rata-rata skor sebesar 3.50 .

Teknik instalasi dilapangan telah menggunakan perbandingan, pemakaian yang sesuai dengan ketentuan yang semestinya yang memiliki rata-rata skor 3.47, variabel pembentukan organisasi kerja secara mutlak dilakukan dengan ratarata skor 3.46, variabel kejelasan otoritas kerja dilapangan pada setiap bagian memiliki rata-rata skor 3.44 , variabel efektifitas dalam pengerjaan proyek dan pelatihan guna meningkatkan keahlian teknis dilapangan memiliki rata-rata skor
3.39, variabel tantangan pekerjaan memiliki rata-rata skor 3.38 , variabel pembentukan organisasi kerja secara mutlak dilakukan dan pembentukan tim untuk mengkordinasi antar bagian memiliki rata-rata skor 3.37, variabel pemberian sanksi yang tegas bagi pekerja yang melanggar peraturan dan proses negosiasi resource untuk penghematan biaya, serta motivasi dalam bekerja memiliki rata-rata skor 3.36, variabel kesesuaian hierarki kekuasaan dalam proyek dan penugasan kerja sesuai dengan keahlian pada masing-masing bidang memiliki rata-rata skor 3.35 , variabel inovasi dalam hal proses penyelesaian proyek untuk menghasilkan efesiensi biaya memiliki rata-rata skor 3.33, variabel biaya untuk optimalisasi kerja teralokasi secara rutin memiliki rata-rata skor 3.32, variabel pengelolaan sumber daya manusia dilakukan dengan profesional memiliki rata-rata skor 3.29, variabel bahan dasar dan materil yang dipakai dengan standar yang telah ditetapkan dan pelaksanaan proyek memperhatikan efesiensi biaya yang dikeluarkan memiliki rata-rata skor 3.27 dan variabel memperhatikan mutu sebuah pekerjaan memiliki rata-rata skor 3.21 .

\section{Analisis Faktor}

Untuk keperluan pembuatan matrix korelasi maka digunakan Kaiser Meyer- 
Olkin and Bartlett's test dan Anti Image Correlation test. MSA adalah ukuran dari matrix korelasi dari masing-masing variabel individual untuk mengevaluasi kecukupan menerapkan faktor analisis. Untuk menguji bahwa ke 23 variabel saling mempengaruhi, hal ini dapat dilihat dari Determinant of Corelation Matrix yang mendekati nol (0), nilai KMO MSA (Kaiser-Meyer Olkin Measure of Sampling

Tabel 4.5 Hasil Tes KMO dan Bartlett's

\begin{tabular}{|l|l|l|}
\hline $\begin{array}{l}\text { Kaiser-Meyer-Olkin } \\
\text { Measure of Sampling }\end{array}$ & $\mathbf{0 . 9 4 4}$ \\
Adequacy. & \\
\hline $\begin{array}{l}\text { Bartlett's Test } \\
\text { of Sphericity }\end{array}$ & $\begin{array}{l}\text { Spprox. Chi- } \\
\text { Square }\end{array}$ & 1409.055 \\
\hline
\end{tabular}

Dari tabel 4.5 diatas di dapatkan nilai uji Kaiser - Meyer - Olkin (KMO) sudah diatas 0.5 dan signifikansi jauh dibawah $0.05 \quad(0.00<0.05)$, maka variabel dan sampel yang ada bisa dianalisis dengan menggunakan analisis faktor. Selain melihat hasil KMO dan Bartlett's test pada tahap pertama ini, juga harus dilihat hasil MSA (Measure of Sampling Adequacy).

Analisis faktor selanjutnya dilakukan dengan Anti Image Matrices. Anti-Image Matrices digunakan untuk menentukan Tabel 4.6 Nilai Anti Image Correlation

\begin{tabular}{|l|l|l|}
\hline No & Variabel & MSA \\
\hline 1 & $\mathrm{X} 1$ & 0.942 \\
\hline 2 & $\mathrm{X} 2$ & 0.929 \\
\hline
\end{tabular}

Adequancy) $>0,5$ serta nilai Sig. $<0,05$ maka korelasi antar variabel adalah cukup kuat sehingga proses analisis faktor dapat dilanjutkan untuk kelompok variabel tersebut (Hair dkk, 1998). Menurut Imam Gozali (2009:307), angka KMO dan Bartlett's Test harus di atas $(0,5)$. Dari hasil pengolahan data dengan IBM SPSS 23 dapat ditampilkan tabel 4.5 yang memuat KMO sebagai berikut:

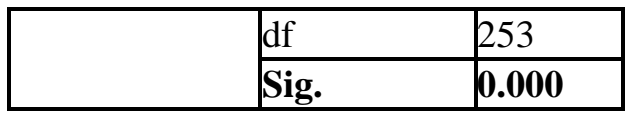

Sumber: Hasil Pengolahan Peneliti dengan IBM SPSS 23, 2018

variabel yang dapat dianalisis lebih lanjut dan variabel mana yang harus dikeluarkan. Bila angka Anti Image Correlation suatu variabel lebih besar dari 0.5 , maka variabel tersebut dapat dianalisis lanjut. Jika angka Anti Image Correlation suatu variabel lebih kecil atau sama dengan 0.5 maka variabel tersebut harus dikeluarkan dan tidak diikutkan pada analisis lanjut. Dari hasil pengolahan data dapat disajikan tabel 4.6 yang memuat Anti Image Correlation sebagai berikut:

\begin{tabular}{|l|l|l|}
\hline No & Variabel & MSA \\
\hline 3 & $\mathrm{X} 3$ & 0.903 \\
\hline 4 & $\mathrm{X} 4$ & 0.938 \\
\hline 5 & $\mathrm{X} 5$ & 0.950 \\
\hline
\end{tabular}




\begin{tabular}{|l|l|l|}
\hline No & Variabel & MSA \\
\hline 6 & X6 & 0.952 \\
\hline 7 & $\mathrm{X} 7$ & 0.938 \\
\hline 8 & $\mathrm{X} 8$ & 0.935 \\
\hline 9 & $\mathrm{X} 9$ & 0.912 \\
\hline 10 & $\mathrm{X} 10$ & 0.955 \\
\hline 11 & $\mathrm{X} 11$ & 0.941 \\
\hline 12 & $\mathrm{X} 12$ & 0.974 \\
\hline 13 & $\mathrm{X} 13$ & 0.954 \\
\hline 14 & $\mathrm{X} 14$ & 0.939 \\
\hline 15 & $\mathrm{X} 15$ & 0.954 \\
\hline 16 & $\mathrm{X} 16$ & 0.937 \\
\hline 17 & $\mathrm{X} 17$ & 0.968 \\
\hline 18 & $\mathrm{X} 18$ & 0.960 \\
\hline 19 & $\mathrm{X} 19$ & 0.925 \\
\hline 20 & $\mathrm{X} 20$ & 0.938 \\
\hline 21 & $\mathrm{X} 21$ & 0.965 \\
\hline 22 & $\mathrm{X} 22$ & 0.952 \\
\hline 23 & $\mathrm{X} 23$ & 0.952 \\
\hline & & \\
\hline
\end{tabular}

Sumber: Hasil Pengolahan Peneliti dengan IBM SPSS 23, 2018

Tabel 4.7 Analisis Communalities

\begin{tabular}{|l|l|l|}
\hline No & Variabel & Extraction \\
\hline 1 & $\mathrm{X} 1$ & 0.699 \\
\hline 2 & $\mathrm{X} 2$ & 0.649 \\
\hline 3 & $\mathrm{X} 3$ & 0.691 \\
\hline 4 & $\mathrm{X} 4$ & 0.519 \\
\hline 5 & $\mathrm{X} 5$ & 0.619 \\
\hline 6 & $\mathrm{X} 6$ & 0.554 \\
\hline 7 & $\mathrm{X} 7$ & 0.654 \\
\hline 8 & $\mathrm{X} 8$ & 0.622 \\
\hline 9 & $\mathrm{X} 9$ & 0.739 \\
\hline 10 & $\mathrm{X} 10$ & 0.533 \\
\hline 11 & $\mathrm{X} 11$ & 0.487 \\
\hline 12 & $\mathrm{X} 12$ & 0.554 \\
\hline 13 & $\mathrm{X} 13$ & 0.589 \\
\hline 14 & $\mathrm{X} 14$ & 0.591 \\
\hline 15 & $\mathrm{X} 15$ & 0.538 \\
\hline
\end{tabular}

Berdasarkan Tabel 4.6 menunjukkan bahwa nilai MSA dari semua variabel sudah memenuhi syarat validitas faktor yaitu lebih besar dari 0.5 dan bisa dilanjutkan untuk analisis lebih lanjut. Sehingga hasil menunjukan variabel layak dan diterima, maka proses analisis dilanjutkan dengan ekstraksi faktor dan mencari nilai communalities dari dua puluh tiga variabel dengan metode Principal Component Analysis pada program SPSS.

Analisis communalities, analisis ini pada dasarnya adalah jumlah varians (bisa dalam presentase) dari suatu variabel mula-mula yang bisa dijelaskan oleh faktor yang ada. persyaratan nilai communalities sendiri adalah lebih besar dari 0,5 (Santoso, 2011:82). Semakin besar nilai kumunalitas sebuah variabel maka semakin erat hubungannya dengan kelompok faktor yang terbentuk.

\begin{tabular}{|l|l|l|}
\hline No & Variabel & Extraction \\
\hline 16 & $\mathrm{X} 16$ & 0.557 \\
\hline 17 & $\mathrm{X} 17$ & 0.502 \\
\hline 18 & $\mathrm{X} 18$ & 0.570 \\
\hline 19 & $\mathrm{X} 19$ & 0.497 \\
\hline 20 & $\mathrm{X} 20$ & 0.619 \\
\hline 21 & $\mathrm{X} 21$ & 0.554 \\
\hline 22 & $\mathrm{X} 22$ & 0.691 \\
\hline 23 & $\mathrm{X} 23$ & 0.527 \\
\hline
\end{tabular}

Sumber: Hasil Pengolahan Peneliti dengan IBM SPSS 23, 2018

Dari tabel 4.7 diketahui bahwa peranan yang terbesar adalah variabel Inovasi dalam hal proses pembangunan perlu dilakukan guna menghasilkan efesiensi 
biaya (X9) sebesar 0.739 atau sebesar $73.9 \%$ serta varibel mengenai bahan dasar dan materil yang dipakai harus bersesuaian dengan standar yang telah ditetapkan dan disepakati bersama (X1) sebesar 0.699 atau sebesar $69.9 \%$.

Proses selanjutnya dari analisis faktor adalah melakukan pengujian Total Variance Explained. Menurut Santoso (2011 :85), menjelaskan bahwa tabel Total Variance Explained menggambarkan jumlah faktor yang terbentuk. Ekstraksi faktor digunakan untuk menentukan jumlah faktor yang akan dipakai/terbentuk. Ekstraksi faktor dalam penelitian ini menggunakan metode PCA (Principal Componen Analysis). Untuk menentukan faktor yang terbentuk. Maka harus dilihat nilai eigenvaluenya harus berada di atas satu (1). Jika sudah berada di bawah satu (1) maka sudah tidak terdapat faktor yang terbentuk. Hasil ekstraksi selengkapnya dapat dilihat pada tabel 4.8, sebagai berikut:

Tabel 4.8 Hasil Ekstraksi Faktor

\begin{tabular}{|c|c|c|c|c|c|c|}
\hline & \multicolumn{3}{|c|}{ Initial Eigenvalues } & \multicolumn{3}{|c|}{ Extraction Sums of Squared Loadings } \\
\hline & Total & $\%$ of Variance & $\begin{array}{l}\text { Cumulative } \\
\%\end{array}$ & Total & $\begin{array}{l}\% \\
\text { Variance }\end{array}$ & Cumulative $\%$ \\
\hline 1 & 11.312 & 49.182 & 49.182 & 11.312 & 49.182 & 49.182 \\
\hline 2 & 1.224 & 5.321 & 54.503 & 1.224 & 5.321 & 54.503 \\
\hline 3 & 1.019 & 4.429 & 58.933 & 1.019 & 4.429 & 58.933 \\
\hline 4 & 0.908 & 3.948 & 62.881 & & & \\
\hline 5 & 0.813 & 3.535 & 66.416 & & & \\
\hline 6 & 0.768 & 3.34 & 69.756 & & & \\
\hline 7 & 0.729 & 3.171 & 72.927 & & & \\
\hline 8 & 0.659 & 2.867 & 75.794 & & & \\
\hline 9 & 0.63 & 2.739 & 78.533 & & & \\
\hline 10 & 0.582 & 2.53 & 81.063 & & & \\
\hline 11 & 0.503 & 2.186 & 83.249 & & & \\
\hline 12 & 0.468 & 2.034 & 85.283 & & & \\
\hline 13 & \begin{tabular}{|l}
0.449 \\
\end{tabular} & 1.952 & 87.234 & & & \\
\hline 14 & 0.423 & 1.839 & 89.073 & & & \\
\hline 15 & \begin{tabular}{|l}
0.389 \\
\end{tabular} & 1.69 & 90.763 & & & \\
\hline 16 & 0.35 & 1.524 & 92.287 & & & \\
\hline 17 & \begin{tabular}{|l}
0.299 \\
\end{tabular} & 1.299 & 93.586 & & & \\
\hline 18 & 0.291 & 1.266 & 94.852 & & & \\
\hline 19 & 0.285 & 1.24 & 96.091 & & & \\
\hline 20 & \begin{tabular}{|l}
0.251 \\
\end{tabular} & 1.092 & 97.184 & & & \\
\hline 21 & 0.247 & 1.073 & 98.257 & & & \\
\hline
\end{tabular}




\begin{tabular}{|l|l|l|l|l|l|l|}
\hline \multirow{2}{*}{} & \multicolumn{3}{|l|}{ Initial Eigenvalues } & \multicolumn{3}{l|}{ Extraction Sums of Squared Loadings } \\
\cline { 2 - 7 } & Total & $\%$ of Variance & $\begin{array}{l}\text { Cumulative } \\
\%\end{array}$ & Total & $\begin{array}{l}\% \\
\text { Variance }\end{array}$ & Cumulative \% \\
\hline 22 & 0.209 & 0.907 & 99.164 & & & \\
\hline 23 & 0.192 & 0.836 & 100 & & & \\
\hline
\end{tabular}

Sumber: Hasil Pengolahan Peneliti dengan IBM SPSS 23, 2018

Seperti yang telah dijelaskan sebelumnya Untuk menentukan faktor yang terbentuk. Maka harus dilihat nilai eigenvaluenya harus berada di atas 1 . Jika sudah berada di bawah 1 maka sudah tidak terdapat faktor yang terbentuk, dari tabel diatas dapat kita ketahui bahwa ada 3 faktor yang terbentuk, karena dengan 1 sampai 3 faktor angka eigenvalues masih diatas 1 yaitu 1.019. Namun untuk 4 faktor angka eigenvalues sudah dibawah 1, yaitu 0.908 , sehingga proses factoring berhenti pada 3 faktor saja. Sampai pada proses ini, terlihat dari dua puluh tiga variabel yang dimasukkan ke dalam analisis faktor terbentuk 3 faktor. Hal ini menunjukkan ada pengelompokkan sejumlah variabel ke faktor tertentu, karena ada kesamaan ciri variabel-variabel tertentu.

Berdasarkan ketentuan tersebut maka terdapat tiga komponen utama yang mempunyai proporsi kumulatifnya berkisar antara 50\% - 60\%. Sehingga kelima komponen utama tersebut merupakan ringkasan informasi terbaik dari sejumlah item yang dianalisis. Pada tabel di atas dapat dijelaskan terbentuknya lima faktor setelah terjadi penyederhanaan dari beberapa item aslinya.

Faktor pertama mampu menjelaskan $49.18 \%$ dari keragaman total item-item penelitian, pada faktor kedua dapat menjelaskan $5.32 \%$ dari keragaman total, sedangkan faktor ketiga dapat menjelaskan $4.43 \%$. Jadi kumulatif ketiga faktor yang terbentuk dapat menerangkan sebesar $58.93 \%$ dari total keragaman item-item penelitian

Tahapan selanjutnya adalah menentukan item-item yang dominan pada setiap komponen tersebut. Hal ini dapat dilihat dari tabel Component Matrix yang menunjukan distribusi item penelitian kelima faktor yang terbentuk. Penelitian ini menggunakan rotasi varimax, yaitu metode yang bertujuan untuk merotasi faktor awal hasil ekstraksi sehingga akan menghasilkan matriks yang lebih sederhana untuk mempermudah interpretasi dengan meminimalkan variabel yang dimiliki loading factor tinggi terhadap faktornya. Setelah jumlah faktor terbentuk maka dilanjutkan dengan proses penetapan variabel. Interpretasi dilakukan dengan melihat factor loading (korelasi) 
suatu variabel dengan faktornya. Loading faktor dapat menjelaskan seberapa besar bisa mengukur faktor yang terbentuk dari tiap- tiap kelompok faktor. Batasan factor loading lebih besar dari 0,5 (Santoso,

Tabel 4.9 Hasil Component Matrix

\begin{tabular}{|c|c|c|c|}
\hline \multirow{2}{*}{ Variabel } & \multicolumn{3}{|c|}{ Component } \\
\hline & 1 & 2 & 3 \\
\hline $\mathrm{X} 22$ & 0.773 & 0.264 & 0.152 \\
\hline $\mathrm{X} 16$ & 0.69 & 0.244 & 0.143 \\
\hline $\mathrm{X} 14$ & 0.683 & 0.204 & 0.288 \\
\hline $\mathrm{X} 20$ & 0.643 & 0.226 & 0.394 \\
\hline $\mathrm{X} 10$ & 0.618 & 0.26 & 0.29 \\
\hline $\mathrm{X} 12$ & 0.617 & 0.361 & 0.206 \\
\hline $\mathrm{X} 13$ & 0.595 & 0.458 & 0.163 \\
\hline $\mathrm{X} 18$ & 0.593 & 0.26 & 0.388 \\
\hline $\mathrm{X} 15$ & 0.591 & 0.26 & 0.347 \\
\hline $\mathrm{X5}$ & 0.581 & 0.389 & 0.361 \\
\hline $\mathrm{X} 21$ & 0.451 & 0.409 & 0.428 \\
\hline X19 & 0.432 & 0.387 & 0.401 \\
\hline $\mathrm{X} 9$ & 0.112 & 0.786 & 0.329 \\
\hline $\mathrm{X} 7$ & 0.225 & 0.751 & 0.198 \\
\hline $\mathrm{X} 8$ & 0.365 & 0.697 & 0.046 \\
\hline $\mathrm{X} 11$ & 0.258 & 0.608 & 0.225 \\
\hline X6 & 0.381 & 0.607 & 0.201 \\
\hline $\mathrm{X} 4$ & 0.387 & 0.565 & 0.223 \\
\hline $\mathrm{X} 23$ & 0.432 & 0.484 & 0.325 \\
\hline $\mathrm{X} 17$ & 0.31 & 0.483 & 0.416 \\
\hline $\mathrm{X} 1$ & 0.243 & 0.28 & 0.75 \\
\hline $\mathrm{X} 3$ & 0.362 & 0.133 & 0.737 \\
\hline $\mathrm{X} 2$ & 0.224 & 0.269 & 0.725 \\
\hline
\end{tabular}

Sumber: Hasil Pengolahan Peneliti dengan IBM SPSS 23, 2018

Adapun variabel yang tidak dimasukkan pada salah satu kelompok faktor, ini disebabkan tidak ditemukannya perbedaan secara nyata kedalam faktor variabel tergabung walaupun setelah mengalami
2004). Semakin besar nilai loading faktor yang dibentuk maka semakin tinggi ranking variabel tersebut didalam faktor tersebut. Berikut matrix component dengan menggunakan software SPSS,

rotasi ulang yaitu variabel X21, X19, X23 dan X17 karena nilainya tidak lebih besar dari cut off point (0.5), sehingga variabel dikeluarkan dari kelompok yang terbentuk. Berdasarkan tabel 4.9 dapat diketahui bahwa dengan 5 kali proses rotasi, dari 23 variabel terdapat 19 variabel yang memiliki angka pembatas cut off point > 0.5 serta menghasilkan 3 (tiga) faktor baru yang direduksi terhadap ke 23 variabel awal. Adapun ke tiga faktor baru tersebut yaitu:

1. Faktor 1, terdiri dari variabel pelatihan guna meningkatkan keahlian teknis dilapangan (X22), efektifitas dalam pengerjaan proyek (X16), motivasi dalam bekerja (X14), pemberian sanksi yang tegas bagi pekerja yang melanggar peraturan (X20), pengelolaan sumber daya manusia dilakukan dengan profesional (X10), staf yang bertanggung jawab dalam pelaksanaan proyek (X12), pembentukan tim untuk mengkordinasi antar bagian (X13), penugasan kerja sesuai dengan keahlian pada masing-masing bidang 
(X18), kesesuaian hierarki kekuasaan dalam proyek (X15) dan proses penyelesaian proyek memperhatikan aktualisasi Kurva 's' (X5). Faktor ini diberi nama faktor sumber daya manusia.

2. Faktor 2, terdiri dari variabel inovasi dalam hal proses penyelesaian proyek untuk menghasilkan efesiensi biaya (X9), pelaksanaan proyek memperhatikan efesiensi biaya yang dikeluarkan (X7), proses negosiasi resource untuk penghematan biaya (X8), pembentukan organisasi kerja secara mutlak dilakukan (X11), pelaksanaan pekerjaan dilapangan diupayakan seifisien dan seefektif mungkin (X6), kesesuaian penyelesaian pekerjaan dengan target dilapangan (X4). Faktor ini diberi nama faktor biaya.

3. Faktor 3, terdiri dari variabel kesesuaian bahan dasar dan materil yang dipakai dengan standar yang telah ditetapkan (X1), memperhatikan mutu sebuah pekerjaan (X3), kesesuaian teknik mencampur bahan materil dengan ketentuan yang telah ditetapkan (X2). Faktor ini diberi nama faktor mutu.

\section{Analisis Regresi}

Analisis Regresi Berganda bertujuan untuk mengetahui apakah Pengaruh Sumber Daya Manusia, Biaya dan Mutu terhadap
Keterlambatan Proyek Jalan maka akan dilakukan serangkaian proses analisis data dengan menggunakan analisis regresi linier sederhana diantaranya pengujian asumsi klasik, model regresi, koefisien korelasi, analisis koefisien determinasi, dan pengujian hipotesis.

Tabel 4.11 One-Sample Kolmogorov-Smirnov Test

\begin{tabular}{|c|c|c|}
\hline & & $\begin{array}{l}\text { Unstandardized } \\
\text { Residual }\end{array}$ \\
\hline $\mathrm{N}$ & & 107 \\
\hline Normal & Mean & -.0259835 \\
\hline Parameters ${ }^{\mathrm{a}, \mathrm{b}}$ & $\begin{array}{l}\text { Std. } \\
\text { Deviation }\end{array}$ & .72283719 \\
\hline Most Extrem & Absolute & .086 \\
\hline Differences & Positive & .084 \\
\hline & Negative & -.086 \\
\hline Test Statistic & & .086 \\
\hline Asymp. Sig. & (2-tailed) & $.051^{\mathrm{c}}$ \\
\hline a. Test distrib & ution is $\mathrm{No}$ & rmal. \\
\hline b. Calculated & from data. & \\
\hline c. Lilliefo & Significa & e Correction. \\
\hline
\end{tabular}

Sumber: Hasil Pengolahan Peneliti dengan IBM SPSS 23, 2018

\section{Pengujian Asumsi Klasik}

\section{Uji Normalitas}

Uji Normalitas pada penelitian ini menggunakan uji Kolmogorov-Smirnov. 
Apabila nilai probabilitas yang diperoleh lebih besar dari 0.05 , dapat disimpulkan bahwa residu dalam model regresi berdistribusi secara normal. Dengan Berdasarkan tabel 4.11 uji Kolmogorov Smirnov terlihat bahwa nilai signifikansi sebesar 0.051 lebih besar dari 0.05. Maka, dapat disimpulkan bahwa data berdistribusi secara normal sehingga model memenuhi salah satu asumsi untuk dilakukan pengujian regresi

\section{Uji Multikolinieritas}

Model regresi linier berganda yang baik seharusnya terbebas dari masalah multikolinearitas. Untuk mendeteksi masalah multikolinearitas dapat dilihat dari nilai VIF. Nilai VIF kurang dari 10, dapat disimpulkan bahwa model terbebas dari masalah multikolinearitas. Uji Berdasarkan tabel 4.12 dapat dilihat bahwa nilai VIF pada variabel Sumber Daya Manusia 2.9, variabel Biaya 2.35, dan variabel Mutu sebesar 1.98, ketiga variabel independent tersebut memiliki nilai VIF di bawah batas yang telah ditetapkan yaitu sebesar 10. Dapat disimpulkan bahwa tidak terdapat masalah multikolineritas antar variabel bebas dalam model.

\section{Heteroskedastisitas}

Uji Heteroskedastisitas bertujuan menguji apakah dalam regresi terjadi ketidaksamaan variance dari residual satu pengamatan ke pengamatan yang lain. Jika menggunakan program IBM SPSS 23 diperoleh hasil uji Kolmogorov-Smirnov (K-S) satu sampel sebagai berikut:

multikolinearitas pada penelitian ini bisa dilihat sebagai berikut:

Tabel 4.12 Uni Multikolinieritas

\begin{tabular}{|c|c|c|c|}
\hline \multirow{2}{*}{\multicolumn{2}{|c|}{ Model }} & \multicolumn{2}{|c|}{$\begin{array}{l}\text { Collinearity } \\
\text { Statistics }\end{array}$} \\
\hline & & Tolerance & VIF \\
\hline \multirow[t]{4}{*}{1} & (Constant) & & \\
\hline & $\begin{array}{l}\text { Sumber } \\
\text { Daya } \\
\text { Manusia }\end{array}$ & .345 & 2.900 \\
\hline & Biaya & .426 & 2.350 \\
\hline & Mutu & .501 & 1.997 \\
\hline
\end{tabular}

Sumber: Hasil Pengolahan Peneliti dengan IBM SPSS 23, 2018

variance dari residual satu pengamatan ke pengamatan lain tetap, maka disebut Homoskesatisitas dan jika berbeda disebut Heteroskedastisitas (Ghazali, 2011). Untuk mendeteksi ada tidaknya pelanggaran asumsi heteroskedastisitas dapat dilihat dengan menggunakan uji glejser, yaitu dengan meregresikan antara varabel bebas dengan nilai absolute residual. Jika hasil regresi tidak signifikan $(\operatorname{sig}>0,05)$, maka dapat dikatakan bahwa variance residual bersifat homogen. Hasil pengujian heteroskedastisitas dapat dilihat sebagai berikut: 
Tabel 4.13 Uji Heteroskedastisitas

\section{Coefficients $^{\mathrm{a}}$}

\begin{tabular}{|c|c|c|c|c|c|c|}
\hline \multicolumn{2}{|c|}{ Model } & \multicolumn{2}{|c|}{$\begin{array}{l}\text { Unstandardized } \\
\text { Coefficients }\end{array}$} & \multirow{2}{*}{ 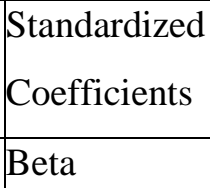 } & & \multirow[t]{2}{*}{ Sig. } \\
\hline & & $B$ & Std. Error & & & \\
\hline \multirow[t]{4}{*}{1} & (Constant) & .293 & .170 & & 1.723 & .088 \\
\hline & $\begin{array}{ll}\text { Sumber } & \text { Daya } \\
\text { Manusia } & \end{array}$ & .019 & .008 & .368 & 1.282 & .075 \\
\hline & Biaya & .002 & .012 & .021 & .144 & .886 \\
\hline & Mutu & -.033 & .021 & -.217 & -1.623 & .108 \\
\hline
\end{tabular}

a. Dependent Variable: Abs_RES

Darihasil pengujian heteroskedastisitas di atas, terlihat bahwa nilai signifikansi yang diperoleh ketiga variabel bebas $>0,05$ yang menunjukan bahwa varians residual dalam data bersifat homokedastisitas, dengan kata lain, tidak ditemukan adanya pelanggaran asumsi heteroskedastisitas.

\section{Autokorelasi}

Model regresi yang baik adalah tidak terdapat autokorelasi dalam model.
Metode pengujian yang digunakan adalah dengan uji Durbin-Watson. Nilai dU dan dL dapat diperoleh dari tabel statistik Durbin Watson yang bergantung pada banyaknya observasi dan banyaknya variabel yang menjelaskan atau variabel independennya. Hasil pengujian dengan menggunakan SPSS ditampilkan dalam tabel sebagai berikut:

Model Summary ${ }^{b}$

\begin{tabular}{|l|l|l|l|l|l|}
\hline Model & R & $\begin{array}{l}\text { R } \\
\text { Square }\end{array}$ & $\begin{array}{l}\text { Adjusted } \\
\text { R Square }\end{array}$ & $\begin{array}{l}\text { Std. Error of the Durbin- } \\
\text { Estimate }\end{array}$ & Watson \\
\hline 1 & $.666^{\mathrm{a}}$ & .444 & .428 & .72097 & 2.015 \\
\hline
\end{tabular}

a. Predictors: (Constant), Mutu, Biaya, Sumber Daya Manusia

b. Dependent Variable: Proyek

Tabel 4.14 Hasil Pengujian Autokorelasi

Sumber: Hasil Pengolahan Peneliti dengan IBM SPSS 23, 2018 
Berdasarkan tabel 4.14 di atas diketahui bahwa DW $=2.015$, dengan taraf $5 \%$ dan $\mathrm{n}=107$ maka diperoleh nilai dU sebesar 1.742, dengan demikian nilai $4-\mathrm{dU}=4-$ $1.742=2.258$. Berdasarkan pengambilan keputusan dinyatakan sebelumnya maka diperoleh dU $(1.742)<$ DW $(2.015)<4-d U$ (2.258) maka dapat disimpulkan bahwa tidak terjadi autokorelasi dalam model. Dengan demikian tidak terjadi hubungan yang kuat antar residual pada model.

\begin{tabular}{|c|c|c|c|c|c|c|}
\hline \multirow{2}{*}{\multicolumn{2}{|c|}{ Model }} & \multicolumn{2}{|c|}{$\begin{array}{l}\text { Unstandardized } \\
\text { Coefficients }\end{array}$} & \multirow{2}{*}{\begin{tabular}{|l}
$\begin{array}{l}\text { Standardized } \\
\text { Coefficients }\end{array}$ \\
Beta
\end{tabular}} & \multirow[b]{2}{*}{$\mathrm{T}$} & \multirow[b]{2}{*}{ Sig. } \\
\hline & & $\mathrm{B}$ & Std. Error & & & \\
\hline \multirow[t]{4}{*}{1} & (Constant) & .374 & .334 & & 1.122 & .264 \\
\hline & $\begin{array}{l}\text { Sumber } \\
\text { Daya } \\
\text { Manusia }\end{array}$ & .081 & .017 & .612 & 4.888 & .000 \\
\hline & Biaya & .006 & .024 & .028 & .252 & .802 \\
\hline & Mutu & .018 & .041 & .046 & .447 & .656 \\
\hline
\end{tabular}

\section{Model Regresi Berganda}

Karena keempat asumsi telah terpenuhi maka langkah selanjutnya yaitu membuat persamaan regresi. Persamaan dari Sumber Daya Manusia, Biaya dan Mutu terhadap Keterlambatan Proyek Jalan dengan menggunakan bantuan aplikasi program IBM SPSS 23, didapat output hasil perhitungan regresi linier berganda sebagai berikut:

Berdasarkan output tabel 4.15 didapat nilai konstanta dan koefisien regresi sehingga dapat dibentuk persamaan regresi linier berganda sebagai berikut:

$\mathrm{Y}=0.374+0.081\left(\mathrm{X}_{1}\right)+0.006\left(\mathrm{X}_{2}\right)+$ $0.018\left(\mathrm{X}_{3}\right)$
Persamaan dari analisis regresi berganda yang tersaji di atas dapat dijelaskan sebagai berikut:

a) Konstanta sebesar 0.374 menunjukkan rata-rata skor Keterlambatan Proyek Jalan jika skor Sumber Daya Manusia, Biaya dan Mutu bernilai nol.

b) Koefisien regresi untuk variabel Sumber Daya Manusia $\left(\mathrm{X}_{1}\right)$ adalah 0.081 yang menunjukkan besar perubahan rata-rata skor Keterlambatan Proyek Jalan yang dipengaruhi oleh Sumber Daya Manusia. 
c) Koefisien regresi untuk variabel Biaya $\left(\mathrm{X}_{2}\right)$ adalah 0.006 yang menunjukkan besar perubahan rata-rata skor Keterlambatan Proyek Jalan yang dipengaruhi oleh Biaya.

d) Koefisien regresi untuk variabel Mutu $\left(\mathrm{X}_{3}\right)$ adalah 0.018 yang menunjukkan besar perubahan rata-rata skor Keterlambatan Proyek Jalan yang dipengaruhi oleh Mutu.

\section{Analisis Koefisien Korelasi dan}

\section{Determinasi}

Model Summary ${ }^{\mathrm{b}}$

\begin{tabular}{|l|l|l|l|l|l|}
\hline Model & $\mathrm{R}$ & $\mathrm{R}$ Square & $\begin{array}{l}\text { Adjusted } \\
\text { R Square }\end{array}$ & $\begin{array}{l}\text { Std. Error of the } \\
\text { Estimate }\end{array}$ & $\begin{array}{l}\text { Durbin- } \\
\text { Watson }\end{array}$ \\
\hline 1 & $.666^{\mathrm{a}}$ & .444 & .428 & .72097 & 2.015 \\
\hline
\end{tabular}

a. Predictors: (Constant), Mutu, Biaya, Sumber Daya Manusia

b. Dependent Variable: Proyek

Sumber: Hasil Pengolahan Peneliti dengan IBM SPSS 23, 2018

Dari hasil diatas dapat diketahui bahwa nilai korelasi (R) Sumber Daya Manusia, Biaya dan Mutu dengan Keterlambatan Proyek Jalan yaitu 0.666 maka koefisien korelasi sebesar 0.666 menunjukan adanya hubungan yang kuat antara Sumber Daya Manusia, Biaya dan Mutu dengan Keterlambatan Proyek Jalan di Jl. Raya Rancaekek - Cileunyi - Nagreg.
Analisis korelasi bertujuan untuk mengetahui kuat atau tidaknya hubungan antara $\mathrm{x}$ dan y apabila dapat dinyatakan dengan fungsi linier (paling tidak mendekati) dan diukur dengan suatu nilai yang disebut koefisien korelasi. Sedangkan koefisien determinasi digunakan untuk melihat persentase pengaruh yang diberikan oleh Sumber Daya Manusia, Biaya dan Mutu secara simultan terhadap Keterlambatan Proyek Jalan. Dengan bantuan program IBM SPSS 23 maka koefisien determinasi diperoleh, sebagai berikut: 


\section{Uji Simultan (F-test)}

Pengujian simultan ini bertujuan untuk menguji keberartian model regresi secara simultan yang digunakan adalah uji statistik F pada taraf keberartian $\alpha=0.05$ (5\%). Uji $\mathrm{F}$ adalah membandingkan $\mathrm{F}_{\text {hitung }}$ dengan $\mathrm{F}_{\text {tabel. }}$.

Tabel 4.17 Hasi Uji Keberartian Regresi Secara Simultan

\section{ANOVA $^{\mathrm{a}}$}

\begin{tabular}{|l|l|l|l|l|l|l|}
\hline \multicolumn{2}{|l|}{ Model } & Sum of Squares & df & $\begin{array}{l}\text { Mean } \\
\text { Square }\end{array}$ & F & Sig. \\
\hline 1 & Regression & 42.762 & 3 & 14.254 & 27.422 & $.000^{\mathrm{b}}$ \\
\cline { 2 - 7 } & Residual & 53.539 & 103 & .520 & & \\
\cline { 2 - 7 } & & & 106 & & & \\
\hline
\end{tabular}

a. Dependent Variable: Proyek

b. Predictors: (Constant), Mutu, Biaya, Sumber Daya Manusia

Berdasarkan Tabel 4.17 di atas didapat nilai Fhitung sebesar 27.422 dengan sig. sebesar 0.000 dengan $\alpha=0.05$ (5\%) serta derajat kebebasan $\mathrm{df}_{1}=\mathrm{k}=3$ dan $\mathrm{df}_{2}=\mathrm{n}$ $(\mathrm{k}+1)=107-(3+1)=103$, maka didapat $\mathrm{F}_{\text {tabel }}=2.690$, sehingga $\mathrm{F}_{\text {Hitung }}$ lebih besar dari $\mathrm{F}_{\text {tabel }} \quad(27.422>2.690)$, selain itu diperoleh hasil nilai sig. sebesar 0.000 lebih kecil dari tingkat keyakinannya $(0.000<0.05)$, yang menunjukkan bahwa nilai hitung berada diwilayah penolakan $\mathrm{H}_{0}$ sehingga $\mathrm{H}_{1}$ diterima. Dengan demikian, penelitian ini menunjukan bahwa regresi berarti, sehingga Sumber Daya Manusia, Biaya dan Mutu berpengaruh signifikan secara simultan terhadap Keterlambatan Proyek Jalan.

\section{Uji Parsial (t-test)}

Uji hipotesis dilakukan dengan cara membandingkan antara $t_{\text {tabel }}$ dengan $t_{\text {hitung. }}$ Pengujian ini bertujuan untuk untuk menguji kemampuan siginifikasi secara parsial hasil penelitian. Adapun uji keberartian koefisien regresi dalam penelitian ini menggunakan IBM SPSS 23 seperti pada Tabel 4.16. Tingkat signifikansi $(\alpha)$ sebesar 5\% dan derajat kebebasan $(\mathrm{df})=\mathrm{n}-(\mathrm{k}+1)=107-(3+1)=$ 103 didapati nilai $t_{\text {tabel }}$ dari nilai $t_{\text {tabel }}$ distribusi t dua pihak sebesar 1.983. Untuk memudahkan memahami kriteria pengujian, nilai $t_{\text {hitung }}$ dan $t_{\text {tabel }}$ dibandingkan. 


\section{Pengaruh Sumber Daya Manusia terhadap Keterlambatan Proyek Jalan}

Pengujian hipotesis mengenai pengaruh Sumber Daya Manusia terhadap Keterlambatan Proyek Jalan di peroleh bahwa nilai $t_{\text {hitung }}$ sebesar 4.888 dengan $t_{\text {tabel }}$ sebesar 1.983. Berdasarkan table 4.16 diperoleh bahwa nilai $t_{\text {hitung }}>t_{\text {tabel }}$ yaitu $4.888>1.983$ dan diketahui sig. $(0.000)<$ 0.05 sehingga $\mathrm{H}_{0}$ ditolak yang artinya bahwa secara parsial Sumber Daya Manusia berpengaruh signifikan terhadap Keterlambatan Proyek Jalan.

\section{Pengaruh Biaya terhadap}

\section{Keterlambatan Proyek Jalan}

Pengujian hipotesis mengenai pengaruh Biaya terhadap Keterlambatan Proyek Jalandiperoleh bahwa nilai $t_{\text {hitung }}$ sebesar 0.252 dengan $t_{\text {tabel }}$ sebesar 1.983 . Berdasarkan tabel 4.15 diperoleh bahwa nilai $t_{\text {hitung }}>t_{\text {tabel }}$ yaitu $0.252<1.983$, selain itu diketahui sig. (0.820) > 0.05 sehingga $\mathrm{H}_{0}$ diterima yang artinya bahwa secara parsial Biaya tidak berpengaruh signifikan terhadap Keterlambatan Proyek Jalan.

\section{Pengaruh Mutu terhadap}

\section{Keterlambatan Proyek Jalan}

Pengujian hipotesis mengenai pengaruh Mutu terhadap Keterlambatan Proyek Jalan diperoleh bahwa nilai $t_{\text {hitung }}$ sebesar 0.447 dengan $t_{\text {tabel }}$ sebesar 1.983 .
Berdasarkan tabel 4.16 diperoleh bahwa nilai $\mathrm{t}_{\text {hitung }}<\mathrm{t}_{\text {tabel }}$ yaitu $0.447<1.983$, selain itu diketahui sig. $(0.656)<0.05$ sehingga $\mathrm{H}_{0}$ diterima yang artinya bahwa secara parsial Mutu tidak berpengaruh signifikan terhadap Keterlambatan Proyek Jalan.

\section{KESIMPULAN DAN SARAN}

\section{Kesimpulan}

Berdasarkan hasil analisis data dan pembahasan mengenai kajian Faktorfaktor yang mempengaruhi keterlambatan penyelesaian proyek jalan di Jl. Raya Rancaekek - Cileunyi - Nagreg, maka dapat diperoleh kesimpulan sebagai berikut:

1. Faktor-faktor yang mempengaruhi keterlambatan penyelesaian proyek jalan di Jl. Raya Rancaekek - Cileunyi - Nagreg, adalah sebagai berikut:

a) Faktor sumber daya manusia yang terdiri dari variabel pelatihan guna meningkatkan keahlian teknis dilapangan (X22), efektifitas dalam pengerjaan proyek (X16), motivasi dalam bekerja (X14), pemberian sanksi yang tegas bagi pekerja yang melanggar peraturan (X20), pengelolaan sumber daya manusia dilakukan dengan profesional (X10), staf yang bertanggung jawab dalam pelaksanaan proyek (X12), pembentukan tim untuk mengkordinasi antar bagian (X13), 
penugasan kerja sesuai dengan keahlian pada masing-masing bidang (X18), kesesuaian hierarki kekuasaan dalam proyek (X15) dan proses penyelesaian proyek memperhatikan aktualisasi Kurva 's’ (X5).

b) Faktor biaya yang terdiri dari variabel inovasi dalam hal proses penyelesaian proyek untuk menghasilkan efesiensi biaya (X9), pelaksanaan proyek memperhatikan efesiensi biaya yang dikeluarkan (X7), proses negosiasi resource untuk penghematan biaya (X8), pembentukan organisasi kerja secara mutlak dilakukan (X11), pelaksanaan pekerjaan dilapangan diupayakan seifisien dan seefektif mungkin (X6), kesesuaian penyelesaian pekerjaan dengan target dilapangan (X4).

c) Faktor mutu yang terdiri dari variabel kesesuaian bahan dasar dan materil yang dipakai dengan standar yang telah ditetapkan (X1), memperhatikan mutu sebuah pekerjaan (X3), kesesuaian teknik mencampur bahan materil dengan ketentuan yang telah ditetapkan (X2).

2. Faktor utama yang mempengaruhi keterlambatan proyek terdapat pada faktor sumber daya manusia dengan nilai keragaman total sebesar $49.18 \%$, selanjutnya faktor biaya dengan nilai keragaman total sebesar $5.32 \%$, dan faktor terakhir yaitu faktor mutu dengan nilai keragaman total sebesar $4.43 \%$.

\section{Saran}

Berdasarkan hasil penelitian dan kesimpulan yang telah dipaparkan, peneliti akan mengajukan saran-saran dengan harapan dapat bermanfaat bagi semua pihak yang berkepentingan. Ada pun saran-saran yang akan peneliti kemukakan adalah,

1. Untuk menurunkan keterlambatan proyek jalan sebaiknya perlu ditingkatkan faktor utama yang ada dalam penelitian ini yaitu faktor sumber daya manusia yang mempengaruhi keterlambatan proyek.

2. Bagi penelitian selanjutnya, perlu dilakukan penelitian lebih lanjut mengenai faktor-faktor lain yang berpengaruh terhadap keterlambatan proyek. Karena berdasarkan hasil penelitian ini menunjukkan bahwa Faktor penyebab keterlambatan proyek jalan hanya terbatas pada faktor-faktor teknis.

\section{DAFTAR PUSTAKA}

Adhiputra, Mhd. Reza, Syahrizal, dan Andy Putra Rambe. (2017). Analisis Faktor Penyebab Keterlambatan Proyek Konstruksi Jalan Tol (Studi Kasus : Jalan Bebas Hambatan MedanKualanamu)Jurnal Teknik Sipil USU. Vol 6 No. 1. 
Ahyari, Agus. (1987). Manajemen Produksi Pengendalian Produksi. Yogyakarta: BPFE.

Andi dkk. (2003). Pengaruh Keterlambatan Proyek Terhadap Pembekakan Biaya Proyek. Surabaya: Universitas Kristen Petra.

Arikunto, Suharsimi. (2006). Prosedur Penelitian Suatu Pendekatan Praktik. Jakarta: Rineka Cipta.

Assaf et al. (1995). Causes of Delay in Large Building Contruction Project. Journal of Management In Engineer.

Austen, A.D dan Neale, R.H. (1984). Manajemen Proyek Konstruksi Pedoman, Proses dan Prosedur. PPM dan PT. Pustaka Binaman Pressindo, Jakarta.

Barrie, Donald S., Paulson Jr., and Boyd C., (1984). Professional Construction Management. McGraw-Hill, Inc., New York.

Callahan, M. (1992)."Contruction Project Scheduling". Mc Graw Hill, New York.

Dipohusodo, Istiawan. (1996). Manajemen Proyek \& Konstruksi. Jilid 2 Kanasius, Yogyakarta.

Ekawati, Ni Luh Yuli. (2015). Analisis Faktor - Faktor Yang Mempengaruhi Keterlambatan Proyek Jalan Lingkungan Permukiman Di Kabupaten Badung. Jurnal Spektran. Vol. 3, No. 2.

Ervianto, W. (1998). Manajemen Proyek Konstruksi. Andi, Yogyakarta.

Ghozali, Imam. (2011). “Aplikasi Analisis Multivariate Dengan Program SPSS". Semarang: Badan Penerbit Universitas Diponegoro.

Hasoloan Benget Sianipar. (2012). Analisis Faktor-Faktor Penyebab Keterlambatan Penyelesaian Proyek Konstruksi Pengaruhnya Terhadap
Biaya. Skripsi. Universitas Sebelas Maret Surakarta.

Hermawan, Antonius Yustino Ryan. (2016). Analisis Faktor-Faktor Keterlambatan Proyek Jalan.Skripsi. Fakultas Teknik. Univeristas Atmajaya Yogyakarta. Yogyakarta.

Langford. (1996). Tata Guna Manajemen Proyek Dalam Bidang Konstruksi. Erlangga, Jakarta.

Lewis, T.M. and Atherley, B. A. (1996). "Analysis of Construction Delays". The Organisation and Management of Construction: Managing the Construction Project and Managing Risk. Vol 2, Eds D.A. Langford \& A. Retik, London: E \& FN Spon, pp 6071.

Nicholas. (1990). Project Management for Business and Technology: Principles and Practice. 2nd edition. Prentice Hall, New Jersey.

O'brien, J. J. (1976). VPM Scheduling For High-Rise Building. Journal of the Construction Division, 1975, Vol. 101, Issue 4, Pg. 895-905.

PMBOK Guide. (2004). A Guide to The Project Management Body of Knowledge. 3th edition. Project Management Institute, Pennsylvania.

Proboyo. B. (1999). Keterlambatan Waktu Pelaksanaan Proyek: Klasifikasi Dan Peringkat Dari PenyebabPenyebabnya. Bandung: Dimensi Teknik Sipil.

Ramang, Ruslan. (2017). Faktor-Faktor Keterlambatan Proyek Jalan Raya Di Kota Kupang Berdasarkan Persepsi Stakeholder. Jurnal Teknik Sipil, Vol. VI, No. 1, April 2017.

Santoso, I. (1999). Analisa Overruns Biaya Pada Beberapa Tipe Proyek Konstruksi. Dimensi Teknik Sipil. Volume 1, No. 1. Hal 40-48. 
Singarimbun, Masri. (2011). Metode Penelitian Survai. Jakarta: LP3ES.

Soeharto, Iman. (1992). Manajemen Proyek: Dari Konseptual Sampai Operasional. Jilid 1. Jakarta: Erlangga.

Sugiyono. (2009). Metode Penelitian Bisnis (Pendekatan Kuantitatif, Kualitatif, dan R\&D).Bandung: Alfabeta.

Sugiyono. (2010). Metode Penelitian Pendidikan Pendekatan Kuantitatif, kualitatif, dan R\&D. Bandung: Alfabeta.

Wibowo. (2008). Manajemen Kinerja. Edisi keempat, Rajawali Pers, Jakarta. 